\title{
Transfer College Quality and Student Performance*
}

\author{
Angela K. Dills \\ Clemson University \\ Rey Hernández-Julián \\ Metropolitan State College of Denver
}

\begin{abstract}
With escalating tuitions, the return to college quality remains an important consideration for students deciding whether to spend more money for a higher quality college education. This paper examines how students that transfer credit for an introductory-level course perform in a subsequent intermediate-level course. Using rich administrative data we estimate how college quality affects student performance, holding constant many observable student characteristics. Students taking introductory courses at higher quality institutions earn higher grades in their intermediate courses than students attending lower quality institutions. This difference is small, but statistically significant. A back of the envelope calculation suggests that, for the average student, the benefit from attending a higher quality institution is more than worth the higher tuition.
\end{abstract}

JEL classification: I20, I21, A22

Keywords: higher education, transfer students, college quality

\footnotetext{
* We thank Brett Dalton, Michael Maloney, and Robert McCormick, who generously offered the Clemson University data. We also thank Sean Mulholland, Tim Sass, the Clemson University brown-bag lunch, and discussants and participants at sessions during the Southern Economic Association and the Allied Social Science Associations meetings for helpful comments. Finally, we thank the Earhart Foundation for research support. The usual caveat applies. Please send comments to Angela Dills, The John E. Walker Department of Economics, Box 341309, Clemson University, Clemson, SC 29634-1309 or to adills@clemson.edu.
} 


\section{Introduction}

College is growing more expensive; inflation-adjusted tuition and fees rose more than 80 percent between 1976 and 2004 and about 44 percent between 1990 and $2004 .{ }^{1}$ Responding to this trend, many students choose to save money by completing some part of their college credits at lower quality institutions before completing their degree program at higher quality institutions. Nationally, about 50 percent of undergraduates attend more than one institution of higher education (NCES 2003a, Table 21-1; Adelman 1999). Not only are transfer students a large part of the college student population, they are becoming increasingly common. The number of undergraduates attending more than one institution of higher education increased from 35.6 percent of students in the 1970s to 51.8 percent in the early 1990s (Adelman, 1999).

We consider how the quality of the school from which a student transfers affects student performance in the receiving school. In particular, we examine how students who transfer introductory-level course credits perform in the subsequent intermediate-level course at a public, four-year Research I university, Clemson University.

We find that higher quality schools are better at generating human capital. Students taking introductory courses at higher quality institutions earn higher grades in their intermediate course than students from lower quality institutions. This difference is small, but statistically significant.

Any analysis estimating the benefits of higher quality institutions must account for selection bias arising from unobservably better students choosing to attend better universities (Behrman, Rosenzweig, and Taubman, 1996). We include a rich set of

\footnotetext{
${ }^{1}$ Authors' calculations using Table 313 from the NCES (2004).
} 
students' academic traits. The estimates are robust to the inclusion of additional controls for student academic attributes suggesting that selection bias is not a significant issue. Measurement error in college quality may attenuate estimates, so we follow Black and Smith (2006) and employ two-stage least squares estimates to reduce this bias.

Many of the existing studies use post-graduation wages as a criterion to estimate the return to college quality. ${ }^{2}$ These estimates combine the returns to human capital with the return to signaling. The return to signaling arises from information conveyed by the student being admitted to the school and completing the degree. Weiss (1995) argues that the signaling value of education comprises a large fraction of the return to schooling. Using grades avoids any return to signaling and focuses on the human capital return. ${ }^{3}$ Grades as an outcome variable presents an additional advantage: in contrast to studies by Monk-Turner (1994) and much of Dale and Krueger (2002), which focus on college graduates, this study observes students during their college careers and includes the ones who may never graduate.

We find that higher quality institutions provide a small increase in student grades. The higher quality schools in our sample charge only slightly higher tuition. Given a labor market return to grades close to 10 percent, the increased grades more than compensate for the increased tuition at higher quality schools.

\footnotetext{
${ }^{2}$ Eide, Brewer, and Ehrenberg (1998) are an exception. They find that attending an elite private college increases the likelihood of attending graduate school, particularly graduate school at a major research institution.

${ }^{3}$ A return to signaling could only arise if the professor knew where the student took the introductory courses and this knowledge affected the student's grade. The transfer information is readily available to the student's academic advisor; however, it is not available to a professor teaching a course. We assume that even if the professor did know, it would not affect how the student is graded. The student's grade reflects his or her learning in the class, which, is a measure of human capital without signal.
} 


\section{Empirical Methodology}

Estimating the value of college quality typically involves estimating a regression of some outcome measure on the characteristics of student $i$ and college $c$ :

$$
\text { outcome }_{i c}=X_{i} \beta^{\prime}+W_{c} \gamma^{\prime}+\varepsilon_{i c}
$$

where $X_{i}$ represents the characteristics of the student and $W_{c}$ represents characteristics of the college from which the student transfers. Unobservable student characteristics in the error term tend to be positively correlated with college characteristics, biasing estimates of $\gamma$ upward. Other researchers have handled this bias by using twins (Behrman, Rosenzweig, and Taubman, 1996), instrumenting with distance between home and colleges (Card, 1993), or instrumenting with other colleges to which students were admitted (Dale and Krueger, 2002). We take a different approach and, ideally, compare identical students who took introductory courses at two different institutions and are subsequently in the same classroom for an intermediate course.

We estimate the effect of transfer college quality on student grades. For student $i$ taking an intermediate course in department $j$ in period $t$, after studying the introductory course in period $p$ at institution $k$, we estimate the following:

$$
\operatorname{grade}_{i j k p}=W_{k p} \gamma^{\prime}+\delta_{j}+\theta_{t}+X_{i} \beta^{\prime}+e_{i j t k p}
$$

where $W_{k p}$ is a vector of school quality characteristics. The department fixed effects, $\delta_{j}$, control for variations across departments in the difficulty of grading. Ideally, we would include professor fixed effects, but the data do not allow us to match faculty members to specific classes. The year dummies, $\theta_{t}$, control for variation across time as with university-wide grade inflation. The vector, $X_{i}$, includes a wide variety of student characteristics to control for student quality. 
We focus on estimates of $\gamma$, how characteristics of colleges attended affect student grades. We consider various measures of college quality: student/faculty ratio, percentage of professors with Ph.D.'s, percentage of applicants admitted, average SAT scores, and tuition. In addition, we consider a college quality index using the principal factor of these measures. To minimize potential downward bias from measurement error, we also estimate equation (2) using the additional college quality measures as instruments for one measure of college quality (Black and Smith, 2006).

Zhang (2005) reconciles findings across the literature and concludes that earnings are higher for students who attend more selective schools. We expect that higher quality schools generate higher levels of human capital than lower quality schools, and that this higher level of human capital is reflected in higher grades.

\section{Potential Biases}

Unbiased estimation of the effect of college quality on student grades requires that the error be uncorrelated with college quality. One way to reduce this correlation is to control for student quality. The richness of our data allows us to include student math SAT scores, gender, race, age, in-state or out-of-state residency status, whether a close relative of the student attended the University, an identifier for the student's home zip code, number of credits transferred, and the number of schools from which the student transfers credits. ${ }^{4}$ The legacy variable represents possible preferential admissions as well as measuring family background. The zip code is a useful measure, as it proxies for both socio-economic status and the student's likely high school. Students are also separated into three categories: those who complete all of their transfer credits prior to attending

\footnotetext{
${ }^{4}$ Using high-school rank or verbal SAT scores or adding measures of the student's past performance, class size, and the SAT scores of a student's classmates generates qualitatively similar results.
} 
Clemson, students who complete all of their transfer credits while enrolled at or inbetween semesters at Clemson, and students who transfer credits both prior to and inbetween semesters at Clemson.

Several potential sources of bias remain. The origins of these biases are subtle making it difficult to sign the direction of the bias.

One problem arises from course selection: not all students choose to take the intermediate course. Students who perform poorly in their introductory classes likely will not take or may withdraw from the intermediate course. Students earning grades lower than a C in the introductory course are unable to transfer it. Our sample omits both types of students. The direction of the resulting bias relies on an assumption of the relative difficulty of grading at different quality institutions. Although we cannot observe the relative grading difficult for all institutions, less than four-year institutions are more likely than four-year institutions to give grades below a C (US Department of Education, 2004). This implies that students from these institutions are both less likely to transfer the introductory course and less likely to take the intermediate course. We do not observe courses which students fail to transfer. However, students that transfer an introductory course from a lower quality institution are less likely to complete the intermediate course at Clemson than those students who take an introductory course at a higher quality institution. This course selection likely biases our estimates downwards. ${ }^{5}$

Another potential source of bias is South Carolina's LIFE scholarship, which may impact where students take transfer credits. LIFE scholarships provide $\$ 5,000$ a year for

\footnotetext{
${ }^{5}$ To grasp the potential magnitude of this bias, we estimate the regressions below treating withdrawals as F's and also estimate the regressions using only general education courses where students are restricted in their course selection. Both variations produce results similar to those reported.
} 
resident students to spend at South Carolina institutions of higher education. ${ }^{6}$ If students maintain a 3.0 grade point average (GPA), independent of the institution, the money is available for up to four years. The GPA requirement may change students’ choice of school quality and bias the school quality estimates. However, we see no change in the estimates pre- and post-LIFE.

A final source of bias is unmeasured ability: two observably identical students that transfer credits from schools of differing quality and then attend Clemson likely differ in unobservable ways. Unobserved ability may be positively correlated with transfer school quality if colleges observe student ability better than the econometrician. Unobserved ability may be negatively correlated with transfer school quality if the ability to leave a poor school to attend a better one signals some positive characteristics and the willingness to leave an excellent school to attend a good one signals some potentially negative traits. Hilmer (2000) finds that a student who transfers to an institution of lower quality than his original one is negatively affected in the job market. Upon transferring to Clemson, most students, 91 percent, improve the quality of school they attend, but some transfer further up the quality distribution than others. The net effect of this selection is unclear.

Measurement error may attenuate the OLS estimates. Estimates using one measure of college quality may not adequately capture the richness of the college experience. We use 2SLS to estimate the effect of higher quality institutions to reduce the attenuation bias and, as expected, correcting for measurement error increases the estimates on college quality.

\footnotetext{
${ }^{6}$ For more details, see the South Carolina Commission on Higher Education.
} 
We expect any lingering bias arising from unobserved student quality or course selection, on net, to downward-bias estimates of the return to school quality, making it difficult to conclude that higher-quality schools better prepare students for intermediate coursework. Our estimates thus produce a lower bound on the return to school quality.

\section{Clemson University Transfer Students and College-of-Origin Characteristics}

Clemson University maintains an extensive archive of data on its students, including every grade awarded and all application, transfer, and enrollment information for students from 1988 to 2002. Although our data originate from a single institution, we observe students transferring from a large variety of colleges and universities. The structure of the data allows consideration of the college quality of a wide distribution of schools while minimizing selection bias. Clemson University admitted all students in the sample; this potentially reduces the variance in unobserved student quality relative to samples that observe students attending a variety of schools. In addition, the outcome variable, student grades in the intermediate courses, are comparable across the sample.

Much of the literature on the return to college quality either focuses on highly selective colleges and universities (e.g., Dale and Krueger, 2002 and Eide, Brewer, and Ehrenberg, 1998) or explicitly compares the return of two-year and four-year institutions (e.g., Kane and Rouse, 1995 and 1999; Grubb, 1995; and Monk-Turner, 1994). Our study 
incorporates all four of these institution types: non-selective and selective, two-year and four-year colleges and universities. ${ }^{7}$

Our study focuses on schools similar to the national distribution. Nationally, schools admit most applicants. Only about 150 of 3,500 non-profit colleges admit less than 50 percent of applicants (Epstein, 2006); 40 percent of institutions are open admission (NCES, 2003b). In our sample, 45 percent of students attend open admission or non-selective schools. The remaining 55 percent are selective, meaning that they do not admit all applicants. The average acceptance rate for schools in the sample is 86 percent; among those that do not admit all applicants, the average acceptance rate is 73 percent. To put this in perspective, the school in our sample ranked highest by US News and World Report (2006), the University of Michigan, accepted 47.4\% of its applicants in 2005-2006. The University of Georgia, ranked $60^{\text {th }}$ nationally, accepted 65 percent in 2005-2006. In the United States, 75 percent of students attend public institutions; in our sample, 81 percent do. The large sample of schools considered in this study present a fairly typical range for college students today. ${ }^{8}$ These institutions vary in listed tuition, enrollment, and student-to-faculty ratios.

We consider grades for students transferring credit for the first course in a sequence and completing the second course at Clemson. ${ }^{9}$ We exclude prerequisites that

\footnotetext{
${ }^{7}$ Non-selective institutions accept any applicant who has received a high-school diploma or a GED; community colleges and two-year colleges are commonly non-selective.

${ }^{8}$ Barron's provides a selectivity ranking composed of the freshman class's SAT and ACT scores, their high school rank, the college's required minimum high-school GPA, and the percentage of applicant's admitted (Barron's, 2000). Although many of these characteristics vary from year to year, Barron's ranking does not. Although useful, its rankings are not ideal for our study as they are noisier, less continuous, and provide little variation. However, estimates using Barron's rankings are consistent with those presented.

${ }^{9}$ We consider junior-level or below courses that list prerequisites. The prerequisites for senior level courses are less likely to be transferred. In addition, the senior-level courses are less likely to be direct continuations of the prerequisites. For example, economics field courses require intermediate
} 
are not a direct introduction to the course. Language courses are the clearest examples of courses included in the sample. The Spanish sequence is SPAN 101, SPAN 102, SPAN 201, and SPAN 202; each course clearly continues the curriculum of the previous one. Table A1 provides the full list of intermediate-level courses and their lower-level prerequisite courses included in the sample. Some courses have multiple prerequisites; some prerequisites are required for multiple courses. For example, Corporate Finance (FIN 306) or Financial Management I (FIN 311) is a prerequisite for Financial Management II (FIN 312); General Chemistry (CH 102) serves as a prerequisite for Survey of Organic Chemistry (CH 201), Introduction to Inorganic Chemistry (CH 205), and Organic Chemistry (CH 223). We exclude AP course credit for prerequisites.

Our sample consists of 4,049 grades in intermediate courses for 3,096 different students. The most frequently transferred courses are Single and Multivariable Calculus, Freshman Composition, General Chemistry, Physics with Calculus, Accounting Concepts, and Elementary Spanish. Students must earn at least a C in the transferred course and have the course approved for transfer credit. Grades, however, are not available for the transferred courses.

Summary statistics for transfer students appear in the top panel of Table 1. With average math SATs of 548, transfer students are of slightly lower quality than the average Clemson student. ${ }^{10}$ Ninety-one percent of transfer students are from South Carolina; 54 percent are male; 31 percent have a close family relative that attended Clemson.

microeconomics but are not explicit continuations of the prerequisite. Freshman courses are listed as 100s, sophomore courses as 200s, and so on.

${ }^{10}$ For students who enroll on or after the fall term of 1996, SAT scores are recentered according to the standards available from the College Board. 
The annual College Board College Handbook provides self-reported measures of college quality. In some years schools do not report certain variables; other variables are reported only by selective schools. For example, an open-admission or non-selective school does not request students' SAT scores or high-school ranks and consequently does not report these measures to the Handbook. A school appears in our sample if students transfer more than five courses from that school to Clemson during any individual year. ${ }^{11}$

The average transfer student attends 1.65 schools before entering Clemson, transferring slightly more than 8 three-credit classes. The average student transfers credits from a small school where 37 percent of professors have Ph.D.s and the SAT Math scores are about 15 points below the Clemson mean. A majority of students transfer from instate schools. More than 24 percent of transfer credits come from the nearby technical colleges. Many in-state schools have written guidelines, particularly for introductory courses, about which courses are eligible for transfer credit for specific Clemson courses. Thus, students planning to transfer could carefully select their courses so as to ensure their ability to transfer these credits, given a satisfactory performance.

\section{Estimation Results}

We estimate the effect of attending a higher quality institution for two separate samples: the full sample of transfer students completing a course sequence and a sample limited to those students transferring from selective institutions. Grades in the intermediate courses are recorded without pluses or minuses as A, B, C, D, or F; we recode these grades as $4,3,2,1$, and 0 . The discreteness of the dependent variable, grade, lends itself to estimation with an ordered probit. These estimates provide insight into

\footnotetext{
${ }^{11}$ The requirement is any five courses, not just the introductory ones used in our study.
} 
differing marginal effects at various grade cut-offs. We focus, however, on the OLS estimates as they capture the cardinal value of a grade: when calculating a student's GPA, an A is twice as good as a C. South Carolina students are particularly interested in their GPA as the LIFE scholarship requires maintaining a 3.0. ${ }^{12}$

We observe students and colleges multiple times; on average, we observe each school 8.48 times a year and each student 1.31 times per year. We conservatively cluster the standard errors by college. This accounts for the multiple observations of each school as well as arbitrary forms of autocorrelation within a transfer school.

\section{Full sample results}

We estimate a regression of student grades on student characteristics, school characteristics, year fixed effects, and department fixed effects. ${ }^{13}$ All college quality characteristics are standardized to have a variance of one. Transfer students possess additional characteristics direct attendees do not such as the number of schools from which the student transfers credits; the number of credits transferred; and whether the transfer credits were taken over the summer, prior to continuous attendance at Clemson, or a combination of the two. Including these transfer-specific controls increases the coefficients on school quality, although not significantly. The similarity in the estimates suggests that downward bias arising from unmeasured ability may not be a large concern. ${ }^{14}$

\footnotetext{
${ }^{12}$ The potential exception to cardinality is the F, which may be more than one point worse than a $\mathrm{D}$, because an F requires the student to retake the course. F's constitute slightly less than 5 percent of our sample or 185 of 4,049 observations. Dropping all the Fs does not significantly affect the findings.

${ }^{13}$ An F-test of these fixed effects finds them to be jointly significant.

${ }^{14}$ Restricting the sample to, for example, the students transferring classes in between semesters produces estimates on college and students characteristics that are similar to those from the full sample. This suggests that we adequately control for student ability even in the more heterogenous sample.
} 
Table 2 presents the results of these OLS and 2SLS regressions. Our variables of interest are the measures of school quality. We deal with these college characteristics in several ways. We enter the characteristics one at a time into the regression; however, this omits some of the information about the quality of colleges. We include all the variables in the regression at the same time, incorporating all of the information but imprecisely estimating coefficients on the highly collinear variables. We achieve a middle ground by using principal components to construct a single factor — college quality — which incorporates the information from the significant variables.

We first add each measure to the regression separately; these estimates appear in column (1). The coefficients all have the expected sign and are similar in magnitude although the effect of reducing the student-faculty ratio is about half the size of the other college quality measures. Transferring from a school with a one standard deviation increase in college quality results in a statistically significant increase of 0.041 to 0.096 grade points.

Estimates including all of the characteristics, shown in column (2), are imprecise. Multicollinearity eliminates any statistical significance, although the coefficients on the college characteristics are jointly significant at the 1 percent level.

We use principal components to generate a single factor of college quality, which best explains the covariance in the statistically significant college quality characteristics: percent admitted, the student faculty ratio, list tuition, and the percentage of professors with Ph.D.s. This single factor explains 69 percent of the covariation in the initial variables. We standardize this factor to mean zero, variance one. A one unit change in the variable reflects a change from a mean school to a school one standard deviation above 
the mean. Schools near the mean Augusta State University, Greenville Tech, and the University of South Carolina at Aiken. Erskine College, Florida International University, SUNY-Plattsburgh, and Spring Hill College are about one standard deviation above the mean. $^{15}$

Estimates on the college quality index are positive and significantly different from zero. A one standard deviation increase in quality increases grades by 0.099 grade-points.

The ordered probit results, in Table 3, present a similar picture in that attending a higher quality institution increases student grades. Higher quality schools increase the probability of earning an " $\mathrm{A}$ ” or "B"; the probability of earning a "C" or lower decreases with higher quality schools.

Concerns of measurement error in the regressions including one measure of college quality motivate 2SLS estimation. We use the additional measures of college quality to instrument for each college characteristic in separate regressions. These estimates appear in column (3) of Table 2. Without additional measures of college quality, we are unable to instrument for the college quality index. The 2SLS estimates for the first three college characteristics are 18 to 55 percent larger than the OLS estimates. The 2SLS estimate on student-faculty ratio is substantially larger. A one standard deviation increase in college quality results in grades that are 0.11 to 0.17 points higher. Selective-only Sample Results

We limit the sample to selective schools so that we can include information on college SAT scores. In addition, this focuses on the upper end of the distribution and the

\footnotetext{
${ }^{15}$ The mean schools, on average, admit 84 percent of applicants, have a student-faculty ratio of 14.9 , tuition of $\$ 4,087$, and 41 percent of their professors have Ph.D.’s. The schools one standard deviation above the mean, on average, admit 75 percent of applicants and have a student-faculty ratio of 11.7 , tuition of $\$ 8902$, and 69 percent of the professors have Ph.D.'s.
} 
benefit attending a higher quality institution among the better schools. Although our sample does not include the most elite institutions, we capture several that currently are either top 100 national research schools or top 100 liberal arts colleges ${ }^{16}$ The results are presented in Table 4.

The first two columns present estimates from entering each college quality characteristic separately. The exception is median SAT Math score and the spread between the $75^{\text {th }}$ and $25^{\text {th }}$ percentile SAT Math score; we include these two SAT measures in the same regression. Among these selective schools, higher quality institutions increase student grades a small amount. The only variable that enters significantly is the median SAT Math score; this estimate is also larger than the estimates on the other coefficients. As only one college characteristic is statistically significant, we do not generate a college quality index. ${ }^{17}$ Estimates including the school characteristics together, as in column (2), are qualitatively similar. The coefficients on the college characteristics are jointly significant.

The ordered probit results, in Table 5, support the finding of higher quality selective institutions leading to small improvements in student grades. Higher quality institutions increase the probability of earning an "A" or a " $\mathrm{B}$ " and reduce the probability of earning a "C" or lower. Schools with a greater fraction of Ph.D. professors, a smaller student-faculty ratio, or higher median SAT scores improve transfer student grades.

\footnotetext{
${ }^{16}$ For example, the sample includes, with 2007 ranks in parentheses, Furman University (41), George Washington (47), Georgia (60), Georgia Tech (38), North Carolina State (81), Penn State (47), Wake Forest (27), Maryland (54), U of Pittsburgh (57), Michigan (24), Delaware (67), and the University of Florida (47).

${ }^{17}$ Estimates using an index constructed from all five of these variables are qualitatively similar to the estimates presented.
} 
The last two columns of Table 4 present 2SLS estimates using the additional college quality measures to instrument for each individual measure in separate regressions. Except for median SAT Math score, the 2SLS estimates are much larger than the OLS estimates. A one standard deviation increase in college quality raises student grades by 0.09 to 0.2 grade points.

\section{Robustness Checks}

We estimate a number of specifications as robustness checks. The value of attending a higher quality institution may depend on the subject of the course. We estimate the regressions separately for the more vocational courses in the sample (e.g., Ceramics; Construction Science; Packaging Science; Parks, Recreation, and Tourism Management; and Textile Engineering). The samples based on these courses are too small for definitive conclusions although there is mildly suggestive evidence that lower quality institutions may be better options for courses that are more vocational courses rather than academic.

A dummy variable for the schools in South Carolina is insignificant and does not significantly change any of the other estimates. The heterogeneity of school quality within an institution may mask its benefits to transfer students. We estimate the regressions in Tables 2 and 4 separately for specific departments. Considering departments individually provides a similar picture of small benefits to selective schools. Estimating the results only for core courses (Calculus, Biology, Chemistry, Accounting, and intermediate language courses) yields similar results. Restricting the sample to only public schools results in smaller but still statistically significant estimates. Including an indicator variables for community colleges raises the point estimates on the other college 
characteristics; the estimate on the community college dummy is typically around a significant -0.10 .

In addition to our primary analysis, we estimate the results including students who take both courses in the sequence at Clemson. Adding these students greatly increases the number of observations and decreases the standard errors, so more of the parameter estimates become significant. Non-transfer students score about 0.1 grade points higher than transfer students in the intermediate courses. These estimates confirm Laband and Peitte (1995) comparison of community college transfers to direct attendees at a four-year college where they all take the intermediate course. Examining the coefficients on the student characteristics, however, suggests that direct attendance students differ in unmeasurable ways from transfer students. Thus, we focus on the estimates using only transfer students to better avoid bias from unmeasured student ability in the error term.

\section{Internal Rates of Return}

Our results clearly show that attending a higher quality institution increases student grades, but to make a more meaningful conclusion we need to compare this benefit to a cost. We use the above estimates to provide a rough calculation of the internal rate of return to taking introductory courses at a higher quality institution. This calculation requires several assumptions on the labor market return to college grades. Datcher-Loury and Garman (1995) convincingly present evidence that the return to a unit increase in GPA in the job market is about 10 percent. ${ }^{18}$ In 2000, the average salary for

\footnotetext{
${ }^{18}$ Other earlier estimates confirm the 10 percent (Jackson and Jones, 1990) or provide a lower estimate of one percent (Wise, 1975). Wise (1975), however, uses an unrepresentative sample of the white, male employees of a large corporation.
} 
an individual with a bachelor’s degree was about \$50,000 (US Statistical Abstract, 2003). We also assume a forty-year working life.

First, we use the OLS estimates on the college quality index from Table 2. This estimate may overstate the actual increase in student grades since the grades in courses not contained in our sample may be unaffected by the quality of the previously attended school. ${ }^{19}$ The largest return to college quality arises from a decrease in the student-faculty ratio. Transferring to Clemson from an institution with a one standard deviation smaller student-faculty ratio—-meaning there are fewer professors for each student—increases a student's grades by 0.174 . At a ten percent return to GPA, this implies a salary increase of 1.7 percent or $\$ 870$. Forty years of slightly higher earnings compared to the difference in average list price ( $\$ 1,862$ per year) implies an internal rate of return of 46.75 percent. Implied internal rates of return using the other 2SLS estimates range from 9.61 to 39.46 percent, averaging about 28 percent.

Most students do not pay list price. Kane (1999) provides net tuition and list tuition figures for public two-year, public four-year, and private four-year institutions (p. 61). Students pay about 85 percent of tuition at public two-year institutions, 72 percent at private four-year institutions, and 78 percent at public four-year institutions. We calculate a more realistic tuition difference for a one standard deviation increase in school quality at the mean. For the full sample, implied internal rates of return range from 13 to 89 percent, averaging about 32 percent. At these rates of return, the average student would benefit from attending a higher quality institution prior to transferring to Clemson.

\footnotetext{
${ }^{19}$ Regressions of students' final GPAs on the quality of transfer school produce estimates similar or of slightly smaller magnitude than the reported estimates that consider grades in intermediate courses.
} 
We perform a similar exercise for the 2SLS estimates from the selective-only sample in Table 4. The average internal rate of return using list price is 23 percent; using estimated paid tuitions, the average internal rate of return is 66 percent.

Pleeter and Warner (2001) observe discount rates of between 10 and 20 percent, with a range of up to 30 percent. Experimental evidence such as Harrison, et. al (2004) supports discount rates of around 28 percent. These studies have also concluded that more educated people have lower discount rates. Students with higher discount rates prefer lower quality schools and their lower average tuition.

The internal rates of return are typically at least as large as previously estimated discount rates. There are clear benefits to attending higher quality schools - both at the mean of our full sample and among selective schools. In addition, to the extent that professors do not know or care where their students have transferred from, the benefit to these higher quality schools arises from increases in human capital and not signaling.

\section{Conclusion}

We use data on students transferring from different institutions to Clemson University to estimate the human capital return from different school characteristics. We control for student quality and characteristics that describe the student's transfer choice. The results suggest that students taking an introductory course at a higher quality, higher priced school earn higher grades in the relevant intermediate course. This human capital effect is small but statistically significant.

Along a wide range of institutional quality, higher quality schools generate more human capital than lower quality ones. Although higher quality schools charge more tuition, the expected increase in college GPA and its labor market returns imply that most 
students would prefer attending the higher quality schools. This is particularly true when considering among the selective schools in our sample. This conclusion relies on estimates from the literature on the labor market return to college grades. Additional data on alumni earnings would provide some additional insight into this question.

This does not address the question of whether transferring is better than continuous enrollment. Including Clemson students in the grade regressions suggests that transfer students from other selective institutions earn letter grades that are 0.10 grade points lower in the intermediate class than students taking the related introductory courses at Clemson. If there is no penalty to transferring, the question of which to attend depends on the difference in prices. The decision to transfer may involve additional considerations, however, such as extending the time to degree completion and costs to changing schools. For those few students transferring to lower quality schools, Hilmer (2000) estimates a significant wage penalty from transferring downward, although his small sample sizes limit statistical inference. 


\section{References}

Adelman, Clifford (1999), Answers in the Tool Box: Academic Intensity, Attendance Patterns, and Bachelor's Degree Attainment - June 1999, Washington, DC: U.S. Department of Education.

Barron's (2000), Barron's Profiles of American Colleges, $24^{\text {th }}$ edition, New York: Barron's Educational Series, Inc.

Behrman, Jere R., Mark R. Rosenzweig, and Paul Taubman (1996), “College Choice and Wages: Estimates Using Data on Female Twins,” The Review of Economics and Statistics, 78(4), 672-685.

Black, Dan. A and Jeffrey A. Smith (2006), "Estimating the Returns to College Quality with Multiple Proxies for Quality,” Journal of Labor Economics, 24(3), 701-728.

Card, David. (1993), “Using Geographic Variation in College Proximity to Estimate the Return to Schooling.” NBER Working Paper \#4483.

The College Board College Handbook (1983-2002), New York: The College Board.

Dale, Stacy Berg and Alan B. Krueger. (2002), Estimating the Payoff to Attending a More Selective College: An Application of Selection on Observables and Unobservables.” Quarterly Journal of Economics 117(4), 1491-1528.

Datcher-Loury, Linda and David Garman (1995), “College Selectivity and Earnings,” The Journal of Labor Economics, 13(2), 289-308.

Eide, Eric, Dominic Brewer, and Ronald Ehrenberg (1998), "Does it Pay to Attend an Elite Private College? Evidence on the Effects of Undergraduate College Quality on Graduate School Attendance,” Economics of Education Review, 17)4_, 371-376.

Epstein, David (2006), “Out of Control Admissions Hype,” Inside Higher Ed, April 12 (http://www.insidehighered.com/news/2006/04/12/admissions)

Grubb, W. Norton (1995), “The Economic Returns to Baccalaureate Degrees: New Evidence from the Class of 1972,” The Review of Higher Education, Summer 1995, 213-231.

Harrison, Glenn W., Morten I. Lau, and Melonie B. Williams (2002), “Estimating Individual Discount Rates in Denmark: A Field Experiment," The American Economic Review, 92(5), 1606-1617.

Hilmer, Michael (2000), "Does the return to university quality differ for transfer students and direct attendees?” Economics of Education Review 19(1), 47-61. 
Jackson, John D. and Ethel B. Jones (1990), “Communications - College Grades and Labor Market Rewards.” Journal of Human Resources 25 (2), 253-266.

Kane, Thomas J. (1999), The Price of Admission, Washington, D.C.: Brookings Institution Press.

Kane, Thomas J. and Cecilia Rouse (1995), "Labor Market Returns to Two- and Four-Year College,” American Economics Review, 85(3), 600-614.

Kane, Thomas J. and Cecilia Rouse (1999), “The Community College: Education Students at the Margin between College and Work,” Journal of Economic Perspectives, 13(1), 63-84.

Laband, David N. and Michael J. Piette (1995), "Does Who Teaches Principles of Economics Matter?” The American Economic Review Paper and Proceedings, May, 85(2), 335-338.

Monk-Turner, Elizabeth (1994), "Economic Returns to Community and Four-Year College Education,” Journal of Socio-Economics 23(1), 44-48.

NCES (2003a), The Condition of Education, Table 21-1 accessed on October 25, 2006 at http://nces.ed.gov/programs/coe/2003/section3/tables/t21_1.asp.

NCES (2003b), Digest of Education Statistics, Table 311 accessed on October 25, 2006 at http://nces.ed.gov/programs/digest/d03/tables/dt311.asp

NCES (2004), Digest of Education Statistics, Table 313 accessed on October 25, 2006 at http://nces.ed.gov/programs/digest/d04/tables/dt04_311.asp

Pleeter, Saul and John Warner (2001), “The Personal Discount Rate: Evidence from Military Drawdown Programs,” American Economic Review, 91 (1), 33-53.

South Carolina Commission on Higher Education, “LIFE Scholarship Program,” Columbia, SC. Retrieved October 28, 2004 from http://www.che400.state.sc.us/StudentServices/LIFE/LIFESchHome.htm.

U.S. Department of Education (2004), National Center for Education Statistics, 2003-04 National Postsecondary Student Aid Study (NPSAS:04). Accessed on October 9, 2006 at http://nces.ed.gov/das/library/tables_listings/show_nedrc.asp?rt=p\&tableID=2993

U.S. News and World Report (2006), “America’s Best Colleges 2007,” August 28, p. 111.

U.S. Statistical Abstract 2003, "School Expenditures by Type of Control and Level of Instruction in Constant (2001-2002) Dollars: 1960 to 2002,” Table 218, p. 147.

Weiss, Andrew (1995), “Human Capital vs. Signaling Explanations of Wages,” Journal of Economic Perspectives 9(4) 133-154. 
Wise, David (1975), “Academic Achievement and Job Performance,” American Economic Review 65(3): 350-366.

Zhang, Liang (2005), "Do Measures of College Quality Matter?: The Effect of College Quality on Graduates' Earnings,” Review of Higher Education, Summer, 571-596. 
Table 1 Summary statistics for students and schools in regression equation

\begin{tabular}{|c|c|c|c|c|}
\hline & Mean & $\begin{array}{l}\text { Std. } \\
\text { Dev }\end{array}$ & Min & Max \\
\hline \multicolumn{5}{|l|}{ Student Characteristics } \\
\hline Grade in intermediate course & 2.562 & 1.06 & 0 & 4 \\
\hline Instate students & 0.89 & 0.31 & 0 & 1 \\
\hline Male students & 0.55 & 0.50 & 0 & 1 \\
\hline Legacy Students & 0.30 & 0.46 & 0 & 1 \\
\hline SAT Math & 548.9 & 77.23 & 240 & 800 \\
\hline SAT Verbal & 539.4 & 88.28 & 210 & 800 \\
\hline Relative HS rank & 48.43 & 60.46 & 0 & 1 \\
\hline Entering age & 20.77 & 2.32 & 15.01 & 45.76 \\
\hline Number of Schools attended & 1.65 & 0.80 & 1 & 6 \\
\hline Total number of credits transferred & 25.50 & 18.26 & 3 & 97 \\
\hline \multicolumn{5}{|l|}{ Transfers credits } \\
\hline before coming to Clemson & 0.40 & 0.49 & 0 & 1 \\
\hline between semesters at Clemson & 0.26 & 0.44 & 0 & 1 \\
\hline both before and between & 0.34 & 0.44 & 0 & 1 \\
\hline \multicolumn{5}{|l|}{ Characteristics of School Attended } \\
\hline Percent Admitted & 0.86 & 0.16 & 0.16 & 1 \\
\hline Tuition Paid & $\$ 4,715$ & $\$ 3,811$ & $\$ 0$ & $\$ 20,767$ \\
\hline \% Prof with Ph.D. at transfer school & 0.37 & 0.28 & 0 & 1 \\
\hline Student/faculty at transfer school & 15.09 & 4.00 & 2.51 & 30.39 \\
\hline SAT Math 25th \%ile (if selective) & 478.70 & 51.22 & 330 & 650 \\
\hline SAT Math 75th \%ile (if selective) & 572.36 & 46.81 & 370 & 760 \\
\hline
\end{tabular}

The unit of observation is a student. Since some of the students transfer more than one course, this number is lower than the number of observations in the regression. The table includes only those observations used in our regressions. There are 3,096 students; we have SAT data for schools for 1,714 of these students. 
Table 2: OLS and 2SLS estimates of performance on student and transfer school characteristics (all schools)

\begin{tabular}{lccc}
\hline & $(1)$ & $(2)$ & $(3)$ \\
\hline & OLS - & OLS - & 2SLS \\
& separate & together & \\
Percent Admitted & $-0.093^{*}$ & -0.048 & $-0.122^{*}$ \\
& $(0.024)$ & $(0.045)$ & $(0.030)$ \\
Tuition (thousands) & $0.080^{*}$ & 0.022 & $0.124^{*}$ \\
& $(0.026)$ & $(0.048)$ & $(0.032)$ \\
\% Professors with Ph.D. & $0.096^{*}$ & 0.043 & $0.113^{*}$ \\
& $(0.026)$ & $(0.061)$ & $(0.027)$ \\
FTE students/FTE professors & $-0.041^{* * *}$ & 0.001 & $-0.174^{* *}$ \\
& $(0.023)$ & $(0.025)$ & $(0.074)$ \\
College Quality & & & \\
& $0.099^{*}$ & & \\
\hline
\end{tabular}

There are 3,033 observations. Year, course subject, student home zip code, and student race fixed effects included but coefficients suppressed. Controls for in-state residency, male, legacy status, student Math SAT score, credits transferred to Clemson, student's starting age at Clemson, the number of schools from which the student transfers credits, and indicator variables for the timing of credits transferred are also included but coefficients suppressed. Standard errors in parentheses, clustered by college. * significant at $10 \%, * *$ significant at $5 \%$; $* * *$ significant at $1 \%$. 
Table 3: Marginal Effect of College Characteristics on Getting a Grade in the Intermediate Course for all Schools

\begin{tabular}{|c|c|c|c|c|c|c|}
\hline & $0(\mathrm{~F})$ & 1 (D) & $2(\mathrm{C})$ & 3 (B) & $4(\mathrm{~A})$ & $\begin{array}{c}\text { Mean of } \\
\text { Quality } \\
\text { Measure }\end{array}$ \\
\hline Percent Admitted & $\begin{array}{c}0.0047 * * * \\
(0.0012)\end{array}$ & $\begin{array}{c}0.0114 * * * \\
(0.0031)\end{array}$ & $\begin{array}{c}0.0159 * * * \\
(0.0044)\end{array}$ & $\begin{array}{c}-0.0105^{* * *} \\
(0.0028)\end{array}$ & $\begin{array}{c}-0.02146 * * * \\
(0.0060)\end{array}$ & 0.000 \\
\hline Tuition (thousands) & $\begin{array}{c}-0.00608 * * * \\
(0.0019)\end{array}$ & $\begin{array}{c}-0.0146 * * * \\
(0.0047)\end{array}$ & $\begin{array}{c}-0.02034^{* * *} \\
(0.0069)\end{array}$ & $\begin{array}{c}* 0135^{* * * *} \\
(0.0044)\end{array}$ & $\begin{array}{c}0.0275^{* * *} \\
(0.0091)\end{array}$ & 0.000 \\
\hline Percent Professors with $\mathrm{PhD}$ & $\begin{array}{c}-0.0055^{* * *} \\
(0.0015)\end{array}$ & $\begin{array}{c}-0.0133^{* * *} \\
(0.0038)\end{array}$ & $\begin{array}{c}-0.0185^{* * *} \\
(0.0056)\end{array}$ & $\begin{array}{c}0.0122 * * * \\
(0.0034)\end{array}$ & $\begin{array}{c}0.0249 * * * \\
(0.0075)\end{array}$ & 0.000 \\
\hline $\begin{array}{l}\text { FTE students/ } \\
\text { FTE professors }\end{array}$ & $\begin{array}{c}0.001724 \\
(0.0016)\end{array}$ & $\begin{array}{c}0.004132 \\
(0.0039)\end{array}$ & $\begin{array}{c}0.005738 \\
(0.0055)\end{array}$ & $\begin{array}{l}-0.00379 \\
(0.0036)\end{array}$ & $\begin{array}{l}-0.0078 \\
(0.0074)\end{array}$ & 0.000 \\
\hline College Quality & $\begin{array}{c}-0.0062 * * * \\
(0.0018)\end{array}$ & $\begin{array}{c}-0.0149 * * * \\
(0.0044)\end{array}$ & $\begin{array}{c}-0.0206^{* * *} \\
(0.0065)\end{array}$ & $\begin{array}{c}0.0138 * * * \\
(0.0041)\end{array}$ & $\begin{array}{c}0.0279 * * * \\
(0.0087) \\
\end{array}$ & 0.000 \\
\hline Percent earning grade: & 0.04 & 0.11 & 0.31 & 0.34 & 0.21 & 2.562 \\
\hline \multicolumn{7}{|c|}{$\begin{array}{l}\text { These ordered probit regressions also include but do not report estimates for: controls for instate, male, } \\
\text { legacy, SAT math score, credits transfers to Clemson, student's starting age at Clemson, the number of } \\
\text { schools the student transferred credits from, and indicator variables for whether the student transfered all } \\
\text { credits prior to or while at Clemson. Year, course subject, student home zip code, and student race fixed } \\
\text { effects are included but coefficients are suppressed. Standard errors in parentheses, clustered by college. * } \\
\text { significant at } 10 \%,{ }^{* *} \text { significant at } 5 \% \text {; *** significant at } 1 \% \text {. }\end{array}$} \\
\hline
\end{tabular}


Table 4: OLS and 2SLS estimates of performance on student and transfer school characteristics (non open-admission schools)

\begin{tabular}{lcccc}
\hline & $(1)$ & $(2)$ & $(3)$ & $(4)$ \\
& OLS - separate & OLS - together & 2SLS - separate \\
\hline Tuition (thousands) & 0.06 & 0.003 & $0.214^{* *}$ & \\
& $(0.054)$ & $(0.057)$ & $(0.085)$ & \\
\% Professors with Ph.D. & 0.059 & -0.014 & $0.168^{*}$ & \\
FTE students/FTE professors & $(0.044)$ & $(0.060)$ & $(0.049)$ & \\
& -0.038 & -0.031 & -0.09 & \\
Median SAT Math & $(0.039)$ & $(0.037)$ & $(0.147)$ & \\
jointly with & & & & $0.127^{* * *}$ \\
75th-25th SAT Math \%iles & $0.117^{*}$ & $0.120^{* *}$ & & $(0.066)$ \\
& $(0.033)$ & $(0.059)$ & & 0.064 \\
& -0.028 & -0.038 & & $(0.132)$ \\
\hline
\end{tabular}

There are 1,669 observations. Year, course subject, student home zip code, and student race fixed effects included but coefficients suppressed. Controls for in-state residency, male, legacy status, student Math SAT score, credits transferred to Clemson, student's starting age at Clemson, the number of schools from which the student transfers credits, and indicator variables for the timing of credits transferred are also included but coefficients suppressed. Standard errors in parentheses, clustered by college. ${ }^{*}$ significant at $10 \%,{ }^{* *}$ significant at $5 \%$; ${ }^{* * *}$ significant at $1 \%$. 
Table 5 Marginal Effect of College Characteristics on Getting a Grade in the Intermediate Course: Selective Schools

\begin{tabular}{|c|c|c|c|c|c|c|}
\hline & $0(\mathrm{~F})$ & 1 (D) & $2(\mathrm{C})$ & $3(\mathrm{~B})$ & $4(\mathrm{~A})$ & $\begin{array}{l}\text { Mean of } \\
\text { Quality } \\
\text { Measure }\end{array}$ \\
\hline Tuition (thousands) & $\begin{array}{c}-0.00397^{*} \\
(0.0021)\end{array}$ & $\begin{array}{l}-0.0126^{*} \\
(0.0068)\end{array}$ & $\begin{array}{l}-0.0219 * \\
(0.0123)\end{array}$ & $\begin{array}{l}0.0093^{*} \\
(0.0053)\end{array}$ & $\begin{array}{l}0.0292 * \\
(0.0161)\end{array}$ & 0.000 \\
\hline $\begin{array}{l}\text { Percent Professors } \\
\text { with } \mathrm{PhD}\end{array}$ & $\begin{array}{c}-0.0033^{* *} \\
(0.0016)\end{array}$ & $\begin{array}{l}-0.0107 * * \\
(0.0051)\end{array}$ & $\begin{array}{c}-0.0186^{* *} \\
(0.0094)\end{array}$ & $\begin{array}{c}0.0079 * * \\
(0.0039)\end{array}$ & $\begin{array}{c}0.0248 * * \\
(0.0124)\end{array}$ & 0.000 \\
\hline $\begin{array}{l}\text { FTE students/ } \\
\text { FTE professors }\end{array}$ & $\begin{array}{c}0.0016 \\
(0.0015)\end{array}$ & $\begin{array}{c}0.0049 \\
(0.0049)\end{array}$ & $\begin{array}{c}0.0085 \\
(0.0087)\end{array}$ & $\begin{array}{l}-0.0036 \\
(0.0035)\end{array}$ & $\begin{array}{l}-0.0113 \\
(0.0117)\end{array}$ & 0.000 \\
\hline Median SAT Math & $\begin{array}{c}-0.0046 * * * \\
(0.0015)\end{array}$ & $\begin{array}{c}-0.0148 * * * \\
(0.0042)\end{array}$ & $\begin{array}{c}-0.0259 * * * \\
(0.0076)\end{array}$ & $\begin{array}{c}0.0111^{* * *} \\
(0.0032)\end{array}$ & $\begin{array}{c}0.0342 * * * \\
(0.0103)\end{array}$ & 0.000 \\
\hline $\begin{array}{l}\text { 75th - 25th SAT Math } \\
\text { Percentiles }\end{array}$ & $\begin{array}{c}0.0015 \\
(0.0012)\end{array}$ & $\begin{array}{c}0.0049 \\
(0.0038)\end{array}$ & $\begin{array}{c}0.0086 \\
(0.0067)\end{array}$ & $\begin{array}{l}-0.0037 \\
(0.0030)\end{array}$ & $\begin{array}{l}-0.0114 \\
(0.0089)\end{array}$ & 0.000 \\
\hline Percent earning grade: & 0.03 & 0.11 & 0.29 & 0.35 & 0.22 & 2.623 \\
\hline \multicolumn{7}{|c|}{$\begin{array}{l}\text { These ordered probit regressions also include but do not report estimates for: controls for instate, male, legacy, } \\
\text { SAT math score, credits transfers to Clemson, student's starting age at Clemson, the number of schools the student } \\
\text { transferred credits from, and indicator variables for whether the student transferred all credits prior to or while at } \\
\text { Clemson. Year, course subject, student home zip code, and student race fixed effects are included but coefficients } \\
\text { are suppressed. Standard errors in parentheses, clustered by college. * significant at } 10 \% \text {, ** significant at } 5 \% \text {; } \\
* * * \text { significant at } 1 \% \text {. }\end{array}$} \\
\hline
\end{tabular}


Table A1 List of courses with prerequisites

\begin{tabular}{|c|c|c|c|}
\hline Subject & Number & Prerequisite & Number \\
\hline Accounting & 301 & Accounting & 204 \\
\hline Accounting & 303 & Accounting & 204 \\
\hline Accounting & 301 & Accounting & 201 \\
\hline Accounting & 303 & Accounting & 201 \\
\hline Accounting & 307 & Accounting & 202 \\
\hline Applied Economics & 302 & Applied Economics & 202 \\
\hline Applied Economics & 303 & Economics & 211 \\
\hline American Sign Language & 102 & American Sign Language & 101 \\
\hline American Sign Language & 201 & American Sign Language & 102 \\
\hline American Sign Language & 202 & American Sign Language & 201 \\
\hline Anthropology & 301 & Anthropology & 201 \\
\hline Anthropology & 320 & Anthropology & 201 \\
\hline Architecture & 152 & Architecture & 151 \\
\hline Architecture & 251 & Architecture & 152 \\
\hline Architecture & 252 & Architecture & 251 \\
\hline Architecture, Arts, and & & Architecture, Arts, and & \\
\hline Humanities & 102 & Humanities & 101 \\
\hline Architecture, Arts, and & & Architecture, Arts, and & \\
\hline Humanities & 203 & Humanities & 102 \\
\hline Architecture, Arts, and & & Architecture, Arts, and & \\
\hline Humanities & 204 & Humanities & 203 \\
\hline Architecture, Arts, and & & Architecture, Arts, and & \\
\hline Humanities & 205 & Humanities & 102 \\
\hline Architecture, Arts, and & & Architecture, Arts, and & \\
\hline Humanities & 206 & Humanities & 205 \\
\hline Astronomy & 302 & Physics & 221 \\
\hline Astronomy & 303 & Physics & 221 \\
\hline Biochemistry & 210 & Chemistry & 102 \\
\hline Biochemistry & 211 & Biochemistry & 210 \\
\hline Biological Science & 100 & Biology & 103 \\
\hline Biological Science & 101 & Biology & 110 \\
\hline Biological Science & 102 & Biology & 103 \\
\hline Biological Science & 102 & Biology & 110 \\
\hline Biological Science & 205 & Biology & 103 \\
\hline Biological Science & 223 & Biological Science & 222 \\
\hline Biology & 102 & Biology & 101 \\
\hline Biology & 104 & Biology & 103 \\
\hline Biology & 111 & Biology & 110 \\
\hline Ceramics and Material & & Ceramics and Material & \\
\hline Engineering & 222 & Engineering & 221 \\
\hline Chemical Engineering & 220 & Chemical Engineering & 211 \\
\hline Chemical Engineering & 311 & Chemical Engineering & 211 \\
\hline Chemical Engineering & 312 & Chemical Engineering & 220 \\
\hline
\end{tabular}




\begin{tabular}{|c|c|c|c|}
\hline Chemical Engineering & 312 & Chemical Engineering & 311 \\
\hline Chemical Engineering & 319 & Chemical Engineering & 211 \\
\hline Chemical Engineering & 319 & Chemical Engineering & 223 \\
\hline Chemical Engineering & 319 & Chemical Engineering & 220 \\
\hline Chemical Engineering & 321 & Chemical Engineering & 220 \\
\hline Chemistry & 102 & Chemistry & 101 \\
\hline Chemistry & 106 & Chemistry & 105 \\
\hline Chemistry & 201 & Chemistry & 102 \\
\hline Chemistry & 205 & Chemistry & 102 \\
\hline Chemistry & 223 & Chemistry & 102 \\
\hline Chemistry & 224 & Chemistry & 223 \\
\hline Chinese & 102 & Chinese & 101 \\
\hline Chinese & 201 & Chinese & 102 \\
\hline Chinese & 202 & Chinese & 201 \\
\hline Chinese & 204 & Chinese & 203 \\
\hline Computer Science & 102 & Computer Science & 101 \\
\hline Computer Science & 220 & Computer Science & 120 \\
\hline Computer Science & 270 & Computer Science & 120 \\
\hline Construction Science & & Construction Science & \\
\hline Management & 202 & Management & 201 \\
\hline Construction Science & & Construction Science & \\
\hline Management & 205 & Management & 203 \\
\hline Construction Science & & Construction Science & \\
\hline Management & 301 & Management & 202 \\
\hline Design & 152 & Design & 151 \\
\hline Design & 251 & Design & 152 \\
\hline Design & 252 & Design & 251 \\
\hline Design & 351 & Design & 252 \\
\hline Design & 352 & Design & 351 \\
\hline Economics & 314 & Economics & 200 \\
\hline Economics & 314 & Economics & 211 \\
\hline Economics & 315 & Economics & 200 \\
\hline Economics & 315 & Economics & 212 \\
\hline Electrical and Computer & & Electrical and Computer & \\
\hline Engineering & 212 & Engineering & 211 \\
\hline Electrical and Computer & & Electrical and Computer & \\
\hline Engineering & 262 & Engineering & 202 \\
\hline Electrical and Computer & & Electrical and Computer & \\
\hline Engineering & 321 & Engineering & 320 \\
\hline Engineering Mechanics & 202 & Engineering Mechanics & 201 \\
\hline English & 102 & English & 101 \\
\hline Experimental Statistics & 311 & Experimental Statistics & 301 \\
\hline Finance & 312 & Finance & 306 \\
\hline Finance & 312 & Finance & 311 \\
\hline Forestry & 102 & Forestry & 101 \\
\hline Forestry & 205 & Forestry & 102 \\
\hline
\end{tabular}




\begin{tabular}{|c|c|c|c|}
\hline French & 102 & French & 101 \\
\hline French & 201 & French & 102 \\
\hline French & 202 & French & 201 \\
\hline French & 221 & French & 102 \\
\hline Geology & 102 & Geology & 101 \\
\hline Geology & 103 & Geology & 102 \\
\hline Geology & 112 & Geology & 101 \\
\hline German & 102 & German & 101 \\
\hline German & 201 & German & 102 \\
\hline German & 202 & German & 201 \\
\hline General Communications & 207 & General Communications & 104 \\
\hline History & 394 & History & 173 \\
\hline Industrial Engineering & 201 & Engineering & 120 \\
\hline Italian & 102 & Italian & 101 \\
\hline Italian & 201 & Italian & 102 \\
\hline Italian & 202 & Italian & 201 \\
\hline Japanese & 102 & Japanese & 101 \\
\hline Japanese & 201 & Japanese & 102 \\
\hline Japanese & 202 & Japanese & 201 \\
\hline Landscape Architecture & 152 & Landscape Architecture & 151 \\
\hline Latin & 102 & Latin & 101 \\
\hline Latin & 201 & Latin & 102 \\
\hline Latin & 202 & Latin & 201 \\
\hline Legal Studies & 313 & Legal Studies & 312 \\
\hline Management & 315 & Marketing & 314 \\
\hline Marketing & 302 & Marketing & 301 \\
\hline Mathematical Sciences & 103 & Mathematical Sciences & 104 \\
\hline Mathematical Sciences & 106 & Mathematical Sciences & 103 \\
\hline Mathematical Sciences & 106 & Mathematical Sciences & 105 \\
\hline Mathematical Sciences & 108 & Mathematical Sciences & 106 \\
\hline Mathematical Sciences & 115 & Mathematical Sciences & 104 \\
\hline Mathematical Sciences & 116 & Mathematical Sciences & 115 \\
\hline Mathematical Sciences & 117 & Mathematical Sciences & 104 \\
\hline Mathematical Sciences & 118 & Mathematical Sciences & 117 \\
\hline Mathematical Sciences & 129 & Mathematical Sciences & 106 \\
\hline Mathematical Sciences & 206 & Mathematical Sciences & 108 \\
\hline Mathematical Sciences & 208 & Mathematical Sciences & 206 \\
\hline Mechanical Engineering & 305 & Engineering & 120 \\
\hline Mechanical Engineering & 303 & Mechanical Engineering & 203 \\
\hline Packaging Sciences & 102 & Packaging Sciences & 101 \\
\hline Packaging Sciences & 202 & Packaging Sciences & 102 \\
\hline Parks, Recreation, and & & Parks, Recreation, and & \\
\hline Tourism Management & 205 & Tourism Management & 101 \\
\hline Parks, Recreation, and & & Parks, Recreation, and & \\
\hline Tourism Management & 315 & Tourism Management & 314 \\
\hline Physics & 208 & Physics & 207 \\
\hline
\end{tabular}




\begin{tabular}{llll} 
Physics & 221 & Physics & 122 \\
Physics & 222 & Physics & 221 \\
Physics & 311 & Physics & 222 \\
Physics & 321 & Physics & 221 \\
& & Polymer and Textile & 303 \\
Polymer and Textile Chemistry & 304 & Chemistry & 101 \\
Portuguese & 102 & Portuguese & 102 \\
Portuguese & 201 & Portuguese & 201 \\
Portuguese & 202 & Portuguese & 101 \\
Russian & 102 & Russian & 102 \\
Russian & 201 & Russian & 201 \\
Russian & 202 & Russian & 201 \\
Sociology & 303 & Sociology & 101 \\
Spanish & 102 & Spanish & 102 \\
Spanish & 201 & Spanish & 121 \\
Spanish & 201 & Spanish & 201 \\
Spanish & 202 & Spanish & 102 \\
Spanish & 221 & Spanish & 121 \\
Spanish & 221 & Spanish & 110 \\
Technology and Human & & Technology and Human \\
Resource Development & 160 & Resource Development \\
Technology and Human & & Technology and Human & \\
Resource Development & 220 & Resource Development & 110 \\
Textile Engineering & 201 & Textile Engineering & 175 \\
Textile Engineering & 201 & Textile Engineering & 176 \\
Textile Engineering & 202 & Textile Engineering & 201 \\
\hline & & &
\end{tabular}

